\title{
Pulmonary involvement in patients with juvenile systemic sclerosis
}

\author{
Adriana I. Céspedes-Cruz',2, Rosa A. Carranza-Muleiro, ${ }^{3,4}$,Elva L. López-Rojas', María P. Cruz-Domínguez ${ }^{2,3}$, \\ Héctor Espinosa-Gan', Jorge Ramírez-Pérez?, Juan M. Moreno-Martínez7, Silvia Moysén-Ramírez \\ Maritza Zeferino-Cruz ${ }^{9}$, Alfonso R. Torres-Jiménez ${ }^{9}$, Irvin Ordoñez-González ${ }^{10}$, and Gabriela Medina2,3,11* \\ ${ }^{1}$ Departamento de Reumatología Pediátrica, Hospital de Especialidades Centro Médico La Raza, Instituto Mexicano del Seguro Social (IMSS), \\ Mexico City; ${ }^{2}$ Universidad Nacional Autónoma de México, Mexico City; ${ }^{3}$ División de Investigación en Salud, Hospital de Especialidades Centro \\ Médico La Raza, IMSS, Mexico City; ${ }^{4}$ Sección de Estudios de Posgrado e Investigación, Escuela Superior de Medicina, Instituto Politécnico \\ Nacional, Mexico City; ${ }^{5}$ Hospital de Gineco-Pediatría 48, IMSS, León, Guanajuato; ${ }^{6}$ Departamento de Cardiología Pediátrica, Hospital de \\ Especialidades Centro Médico La Raza, IMSS, Mexico City; ${ }^{7}$ Departamento de Radiología, Hospital de Especialidades Centro Médico La Raza, \\ IMSS, Mexico City; ${ }^{8}$ Departamento de Neumología, Hospital de Especialidades Centro Médico La Raza, IMSS, Mexico City; ${ }^{9} \mathrm{Hospital}$ General \\ Gaudencio González Garza, Centro Médico La Raza, IMSS, Mexico City; ${ }^{10}$ Universidad Veracruzana, Campus Veracruz, Veracruz, Veracruz; ${ }^{11}$ Unidad \\ de Investigación en Medicina Traslacional, Hospital de Especialidades Centro Médico La Raza, IMSS, Mexico City. Mexico
}

\begin{abstract}
Background: Pulmonary involvement in juvenile systemic sclerosis (JSSC) is rare in children and contributes to morbimortality. This study aimed to describe the pulmonary function and clinical, radiologic, and tomographic findings in JSSc. Methods: Patients with JSSc between 5-14 years of age were included. Clinical, functional, and imaging characteristics were assessed. Patients were excluded if they showed lung disease not associated with JSSc: mixed connective tissue disease, overlap syndrome, or acute cardiopulmonary failure at the time of the study. All patients underwent physical examination, electrocardiogram, spirometry, chest X-ray, high-resolution computed tomography (HRCT) of the chest, echocardiography, lung function tests, and the 6-minute walk test (6-MWT). Descriptive statistics were employed for data analysis. Results: We studied 15 patients with the following characteristics: median age, 11 years; median since symptoms onset, 6 years; median since JSSC diagnosis and the finding of pulmonary involvement, 2 years. Lung disease was detected in $73 \%$, interstitial lung disease (ILD) the most common affection (67\%); pulmonary hypertension was found in 6.6\%. 6-MWT was positive in 26.6\%, forced vital capacity (FVC) was abnormal in $26.6 \%$. No pulmonary involvement was found in four patients. Conclusions: The most frequent pulmonary affection in JSSC was ILD. Thus, early JSSC detection and periodic lung monitoring are mandatory to avoid further complications once JSSC is diagnosed.
\end{abstract}

Keywords: Juvenile systemic sclerosis. Interstitial lung disease. High resolution computed tomography.

\section{Afección pulmonar en pacientes con esclerosis sistémica juvenil}

\section{Resumen}

Introducción: La afección pulmonar en la esclerosis sistémica juvenil (ESJ) es rara en niños y contribuye a la morbimortalidad. El objetivo de este estudio fue describir los hallazgos de función pulmonar, clínicos, radiológicos y tomográficos en la

Correspondence:

${ }^{*}$ Gabriela Medina

E-mail: dragabymedina@yahoo.com.mx
Available online: 17-09-2021

Date of reception: 24-09-2020 Date of acceptance: 01-12-2020 DOI: 10.24875/BMHIM.20000301
Bol Med Hosp Infant Mex. 2021;78(5):385-394

www.bmhim.com 1665-1146/C 2020 Hospital Infantil de México Federico Gómez. Published by Permanyer. This is an open access article under the CC BY-NC-ND license (http://creativecommons.org/licenses/by-nc-nd/4.0/). 
ESJ. Métodos: Se incluyeron pacientes con ESJ de 5-14 años de edad. Se evaluaron las características clínicas, funcionales y de imagen. No se incluyeron pacientes con enfermedades pulmonares no asociadas con ESJ en el momento del estudio: enfermedad mixta del tejido conectivo, síndrome de superposición o insuficiencia cardiopulmonar aguda. Se realizaron exploración física, electrocardiograma, espirometría, radiografía de tórax, tomografía computarizada de alta resolución de tórax, ecocardiografía, pruebas de función pulmonar y prueba de caminata de 6 minutos (PC6M). Se utilizó estadística descriptiva para el análisis de los datos. Resultados: Se estudiaron 15 pacientes con las siguientes características: mediana de edad, 11 años; mediana desde el inicio de los síntomas, 6 años; y mediana desde el diagnóstico de ESJ y hallazgo de afección pulmonar, 2 años. Se detectó enfermedad pulmonar en el 73\%. La enfermedad pulmonar intersticial (EPI) fue la afección más común (67\%) y se encontró hipertensión pulmonar en el 6.6\%. La PC6M fue positiva en el 26.6\%, y la capacidad vital forzada resultó anormal en el $26.6 \%$. Cuatro pacientes no presentaron afección pulmonar. Conclusiones: La afección pulmonar más frecuente en la ESJ fue la EPI. La detección temprana de ESJ y la monitorización pulmonar periódica son obligatorias para evitar más complicaciones una vez diagnosticada la ESJ.

Palabras clave: Esclerosis sistémica juvenil. Enfermedad pulmonar intersticial. Tomografía computarizada de alta resolución.

\section{Introduction}

Juvenile systemic sclerosis (JSSc) is a multisystem connective tissue disease of unknown etiology characterized by skin induration and generalized fibrosis of internal organs in patients younger than 16 years of age. The incidence varies between $0.27-0.50$ per million children per year in the United Kingdom and Finland, and less than $5 \%$ of systemic sclerosis (SS) starts in infancy ${ }^{1,2}$. Pleuro-pulmonary manifestations in JSSc are rare, but they associate with morbidity and mortality. The most important and fatal pulmonary complications are interstitial lung disease (ILD) and pulmonary arterial hypertension (PAH) ${ }^{3}$. Interstitial pulmonary fibrosis occurs in approximately one in four children. Knowledge about the pathogenesis, diagnosis, prognosis, and treatment of pediatric ILD and PAH is limited. Laboratory and imaging studies remain essential for early diagnosis, appropriate evaluation, and effective treatment. However, the rarity of JSSC and late diagnosis of its pulmonary complications lead to progressive lung damage ${ }^{4}$. A few studies on JSSc have comprehensively described pulmonary evaluation ${ }^{5-8}$. Therefore, this study aimed to describe the clinical aspects, pulmonary function parameters, and imaging findings in JSSc.

\section{Methods}

JSSc patients between 5-14 years of age who consecutively arrived at a Pediatric Rheumatology Service in a tertiary referral hospital in 2019 were included in the study and classified based on the preliminary classification criteria for JSSc (Paediatric Rheumatology European Society/American College of Rheumatology/ European League Against Rheumatism provisional classification criteria for JSSc) ${ }^{9}$. Patients with pulmonary disease not associated with JSSc, mixed connective tissue disease, overlap syndrome, or acute cardiopulmonary failure were excluded. All patients underwent a complete physical examination and the following tests: anti-nuclear antibodies, anti-nucleolar and anti-centromere antibodies by indirect immunofluorescence using Hep2 cells as substrate, and anti-Scl-70 (anti-topoisomerase I) antibodies by enzyme-linked immunosorbent assay (ELISA) according to the manufacturers' instructions. In addition, we obtained electrocardiogram (EKG), spirometry (Sibelmed, Datospir 120), chest X-ray, and high-resolution computed tomography (HRCT) (Phillips, Brillance model) using the Wells scale. HRCT was performed by two radiologists blinded to the patients' clinical data (RPJ and MMJM), obtaining a kappa coefficient of interobserver agreement $=0.87$. Pulmonary function tests and the 6-minute walk test (6MWT) were also performed according to published guidelines along a 30-meter corridor and standardized normal values for Mexican children ${ }^{10,11}$. Patients were classified as limited (I-JSSc) or diffuse (d-JSSc) skin subtypes according to the modified Rodnan skin score (maximum total score of 51$)^{12}$. Heart rate, respiratory rate, and oxygen saturation were measured with pulse oximetry (minicort oximeter model LR78469) using the Fan and Kozinetz severity-of-illness score ${ }^{13}$.

Interstitial lung disease was considered when chest radiography showed diffuse opacity, confirmed by chest HRCT by Wells scale or restrictive pattern on spirometry according to what has been reported in Mexican students between 8 and 20 years of age $\mathrm{e}^{14}$ or oxygen saturation reduction by pulse oximetry on 6MWT. The World Health Organization functional class for PAH is not explicitly designed for children, although it correlates with 6MWT and hemodynamic parameters ${ }^{15}$. PAH was 
observed with values $\geq 30 \mathrm{mmHg}$ by echocardiogram: mild PAH between $36-50 \mathrm{mmHg}$, moderate $\mathrm{PAH}$ between $50-100 \mathrm{mmHg}$, and severe $\mathrm{PAH}$ with $\geq 100 \mathrm{mmHg}^{16}$. Evaluation of spirometry parameters included forced vital capacity (FVC) and forced expiratory volume in 1 second (FEV1) in a standing position.

The study was conducted following the Declaration of Helsinki (revised in Brazil 2013) and approved by the local Ethics Committee of the Hospital. All parents provided a written informed consent form.

\section{Statistical analysis}

Descriptive analysis was performed. Data were presented as mean \pm standard deviation or median and interquartile range according to the distribution of variables. Analyses were performed using Statistical Package for the Social Sciences software, SPSS Inc, Chicago, Illinois for Windows (version 20.0).

\section{Results}

\section{Clinical characteristics of the patients}

We studied 15 patients with an age of disease onset of $7.6 \pm 2.7$ years and a median follow-up of 12 months. The median time from JSSc diagnosis to the appearance of pulmonary disease was 2 years. Three patients informed a family history of autoimmune disease: a grandmother with systemic lupus erythematosus, a mother with rheumatoid arthritis, and a cousin with SS. Clinical characteristics are shown in Tables 1 and 2.

\section{Pulmonary findings}

Pulmonary disease was detected in 11/15 patients (73\%). ILD was the most common condition in 10/11 (90\%); one patient showed asymptomatic PAH not associated with ILD (sPAP $44 \mathrm{mmHg}$ ). Consent for cardiac catheterization was not obtained in the patient with PAH. Respiratory symptoms such as dyspnea, chronic cough, stridor, and chest tightness occurred in 11 patients (73.3\%), with dyspnea and chronic cough being the most prominent symptoms. Pulmonary findings, spirometry changes, Fan severity scale, and HRCT findings are shown in Tables 3 and 4. Spirometry reported restrictive pattern in four (26.6\%) and obstructive pattern in five patients (33.3\%) (FEV1 and FVC $<80 \%$ ). The $6 \mathrm{MWT}$ was abnormal in four patients $(26.6 \%)$, and both tests were abnormal in only one
Table 1. Characteristics of patients with juvenile systemic sclerosis

\begin{tabular}{|c|c|c|}
\hline Demographic characteristics & $\begin{array}{l}\text { Median } \\
(n=15)\end{array}$ & Range \\
\hline Age (years) & 11 & $4-14$ \\
\hline Sex (female/male) & $13 / 2$ & Ratio 9:1 \\
\hline Juvenile systemic sclerosis & $\begin{array}{c}\text { Diffuse } \\
\text { n (\%) }\end{array}$ & $\begin{array}{c}\text { Limited } \\
\text { n (\%) }\end{array}$ \\
\hline Clinical subtype & $6(40)$ & $9(60)$ \\
\hline $\begin{array}{l}\text { Female } \\
\text { Male }\end{array}$ & $\begin{array}{c}6(46) \\
0\end{array}$ & $\begin{array}{c}7(54) \\
2(100)\end{array}$ \\
\hline Disease progression & Median & Range \\
\hline Time since initial symptoms (years) & 6 & $3-11$ \\
\hline Time of follow-up (months) & 12 & $2-72$ \\
\hline Clinical manifestations & n (\%) & \\
\hline $\begin{array}{l}\text { Cutaneous } \\
\text { Sclerodactyly } \\
\text { Calcinosis } \\
\text { Salt and pepper spots }\end{array}$ & $\begin{array}{c}12(80) \\
4(26.7) \\
3(20)\end{array}$ & \\
\hline $\begin{array}{l}\text { Peripheral vascular } \\
\text { Raynaud's phenomenon } \\
\text { Telangiectasias } \\
\text { Digital ulcers }\end{array}$ & $\begin{array}{l}13(86.7) \\
7(46.7) \\
7(46)\end{array}$ & \\
\hline $\begin{array}{l}\text { Musculoskeletal } \\
\text { Arthritis }\end{array}$ & $4(26.7)$ & \\
\hline $\begin{array}{l}\text { Serologic } \\
\text { Anti-topoisomerase I (Scl 70) } \\
\text { ANA anticentromere }\end{array}$ & $\begin{array}{l}4(26.7) \\
4(26.7)\end{array}$ & \\
\hline $\begin{array}{l}\text { Modified Rodnan skin score for skin } \\
\text { thickening } \\
\text { Normal } \\
\text { Mild (0-14) } \\
\text { Moderate (15-29) } \\
\text { Severe (30-39) }\end{array}$ & $\begin{array}{c}0 \\
7(46.7) \\
7(46.7) \\
1(6.7)\end{array}$ & \\
\hline
\end{tabular}

ANA, anti-nuclear antibodies.

patient. Interstitial lung disease was present in $10 / 15$ patients (67\%), according to the Fan scale.

HRCT revealed ground-glass images in almost half of the patients. Only two patients were asymptomatic with no imaging abnormalities. Figure 1 shows the chest HRCT of a patient with JSSC and pulmonary involvement with interstitial thickening, typical of ILD. Four patients $(26.7 \%)$ with the diffuse variety were positive to anti-topoisomerase I antibodies.

Some patients with the d-JSSc variety with severe cutaneous involvement were already receiving cyclophosphamide when the study was being conducted. When pulmonary involvement was found, they continued 


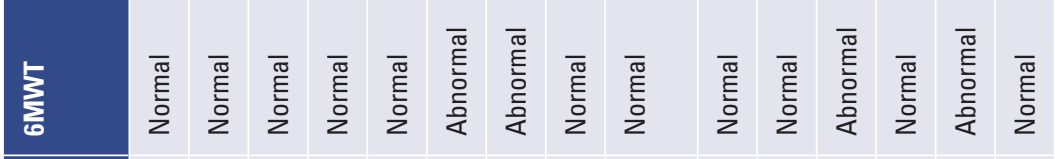

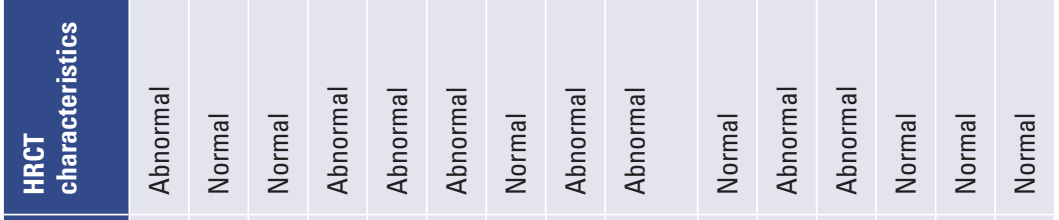

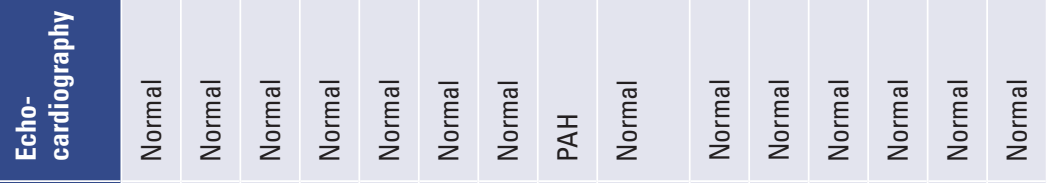

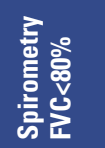

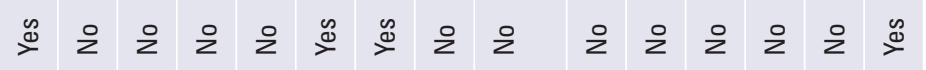

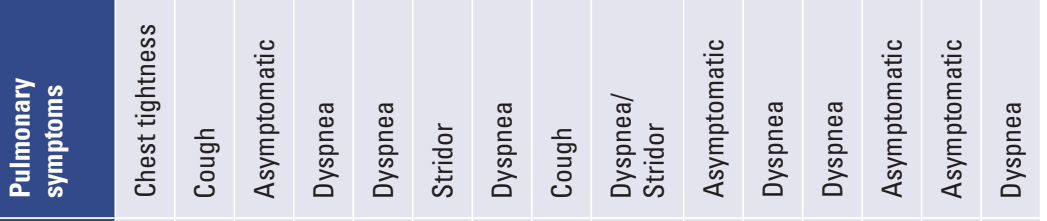

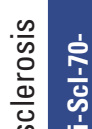

定

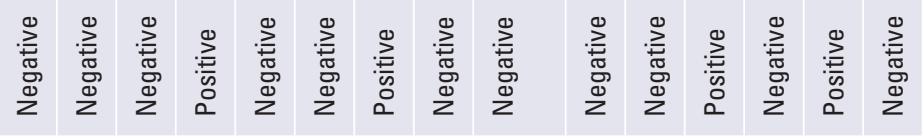

迹

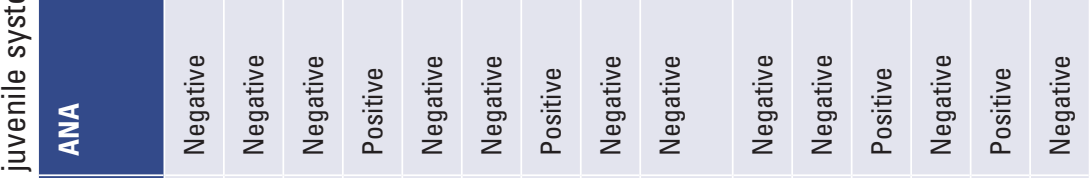

言

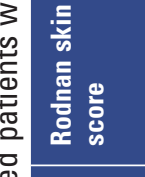

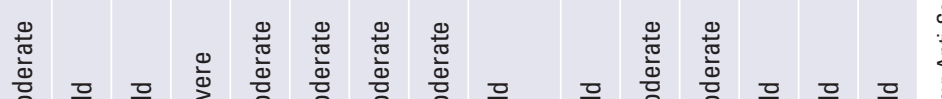

항

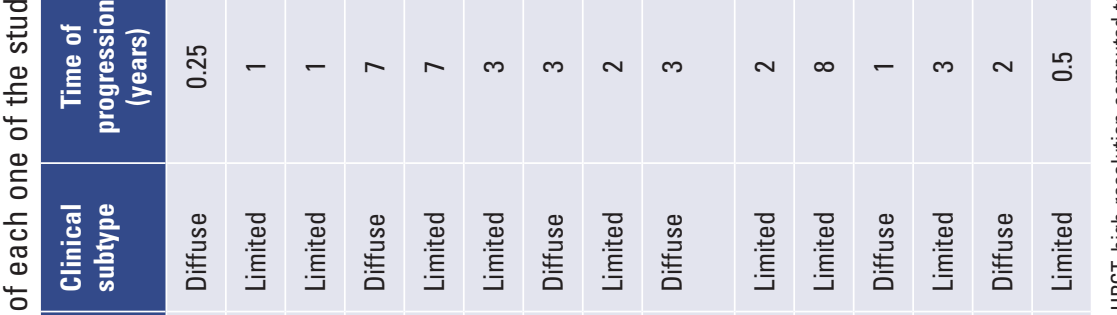



तั

离

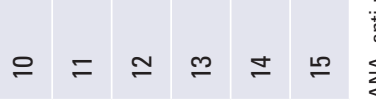


Table 3. Pulmonary involvement in patients with juvenile systemic sclerosis

\begin{tabular}{|l|c|}
\hline Pulmonary involvement & $\mathbf{n}(\%)$ \\
\hline Interstitial lung disease & $10(67)$ \\
\hline Pulmonary arterial hypertension & $1(6.6)$ \\
\hline Lung disease (symptoms) & $\mathbf{n}(\%)$ \\
\hline Chronic cough & $4(26.7)$ \\
\hline Asymptomatic & $2(13.3)$ \\
\hline Dyspnea & $7(46.7)$ \\
\hline Stridor & $2(13.3)$ \\
\hline Chest tightness & $2(13.3)$ \\
\hline Changes in spirometry & Abnormal test \\
\hline PAP, median (min-max) & $\mathbf{n}(\%)$ \\
\hline FVC, median (min-max) & $28(20-44)$ \\
\hline FVC < 80\% & $88(63-115)$ \\
\hline 6 GWW+ & $4(26.6)$ \\
\hline FVC+ 6MWT+ & $4(26.6)$ \\
\hline Fan severity scale (oxygen saturation) & $1(7)$ \\
\hline a Grade I & $\mathbf{n}(\%)$ \\
\hline b Grade II & $4(26.7)$ \\
\hline c Grade III & $7(46.7)$ \\
\hline d Grade IV & $3(20)$ \\
\hline e Grade V & 0 \\
\hline & $1(6.7)$ \\
\hline
\end{tabular}

FVC, forced vital capacity; 6MWT, 6-minute walk test; PAP, pulmonary artery pressure.

Fan severity scale in children with interstitial lung disease (ILD): asymptomatic; ${ }^{b}$ Symptomatic with normal oxygen saturation; ' ${ }^{\circ}$ Symptomatic with exercise desaturation (<90\%); dSymptomatic with resting oxygen desaturation;

eSymptomatic with pulmonary arterial hypertension.

with their treatment regimen, and supplemental oxygen or immunosuppressive treatment was added in those who had no previous treatment.

\section{Discussion}

In the present study, ILD was present in a high proportion of JSSc patients, whereas PAH was present in only one patient. These findings were observed soon after the diagnosis of JSSc in patients with mild clinical findings. Only a few patients showed abnormal pulmonary function tests (PFTs) and 6MWT, regardless of the presence of ILD. It should be considered that ILD and $\mathrm{PAH}$, or a combination of both, are the leading causes
Table 4. Imaging studies in patients with juvenile systemic sclerosis

\begin{tabular}{|l|c|}
\hline Radiographic findings & n (\%) \\
\hline Abnormal chest X-ray & $10(67)$ \\
\hline Interstitial infiltrates & $8(53.3)$ \\
\hline Lung overdistension & $7(47)$ \\
\hline Pulmonary artery dilation & $9(60)$ \\
\hline Bronchiectasis & $3(20)$ \\
\hline HRCT (Wells' score) & $\mathbf{n}(\%)$ \\
\hline Abnormal HRCT & $10(67)$ \\
\hline Ground glass opacity & $7(46.7)$ \\
\hline Grade 0 & $0(0)$ \\
Grade 1 & $6(40)$ \\
\hline Grade 2 & $1(6.7)$ \\
\hline Grade 3 & $0(0)$ \\
\hline Honeycombing & $1(6.7)$ \\
\hline Fine fibrosis & $3(20)$ \\
\hline Grade 0 & $0(0)$ \\
Grade 1 & $5(33)$ \\
\hline Grade 2 & $1(7)$ \\
\hline Grade 3 & $0(0)$ \\
\hline Macrocystic pattern (air spaces $>4 \mathrm{~mm})$ & $7(46.6)$ \\
\hline Microcystic pattern (air spaces $<4 \mathrm{~mm})$ & $1(7)$ \\
\hline Grade 1 & $0(0)$ \\
\hline Grade 2 3 & $1(7)$ \\
\hline Grade 4 & $0(0)$ \\
\hline & $0(0)$ \\
\hline
\end{tabular}

HRCT, high-resolution computed tomography of the chest.

of death in $\mathrm{JSSc}^{17,18}$. In general, survival rates of JSSC are higher than those in adults, probably due to the involvement of internal organs and extension of the disease in older patients.

Furthermore, management during childhood differs from that of adulthood. Classically, respiratory involvement is defined by the following factors: pulmonary fibrosis (on chest X-ray or HRCT), reduced diffusing capacity of the lungs for carbon monoxide (DLCO, in carbon monoxide diffusion test) $<80 \%$ and FVC $<80 \%$, or PAH (assessed by echocardiography) ${ }^{3}$. The ILD prevalence is frequently underestimated, depending on the methodology used to identify fibrotic changes. Almost a quarter of the patients in this study showed no pulmonary involvement. Furthermore, patients with pulmonary involvement are usually diagnosed late. It is important to mention that pulmonary fibrosis can develop silently. Therefore, when clinical symptoms become detectable, structural remodeling is already 

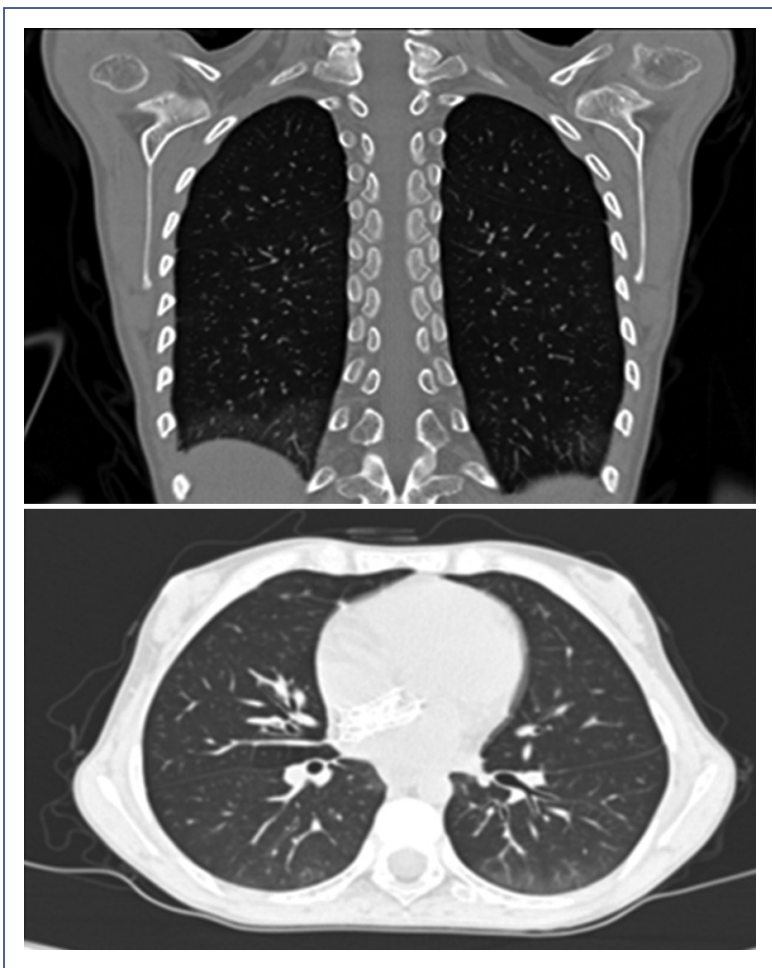

Figure 1. High-resolution computed tomography (HRCT) of a patient with juvenile systemic sclerosis (JSSc) and pulmonary involvement showing interstitial thickening typical of interstitial lung disease (ILD).

established and often advanced. The most common symptoms are chronic cough and dyspnea. The diagnosis of pulmonary disease in JSSc is often established in asymptomatic patients because a few patients present with dyspnea or persistent cough. A high proportion of pulmonary compromise is identified in children by HRCT, pulmonary function tests, or chest radiography ${ }^{19}$. Previous studies demonstrated that $\mathrm{HRCT}$ is the most sensitive imaging modality for lung involvement in SSc and is considered the gold standard for specific pulmonary abnormalities ${ }^{20}$.

Moreover, chest $\mathrm{X}$-rays are normal until late in the course of the disease, and the presence of fibrosis in ILD is an independent predictor of death ${ }^{19,21}$. Another study showed alterations in both HRCT and chest radiography at the diagnosis and during follow-up but in a lower percentage. The most common HRCT finding in JSSc includes ground-glass opacities and irregular linear opacity, similar to our results ${ }^{21}$. Imaging evaluation plays an essential role in the diagnosis, prognosis, and treatment of $\mathrm{JSSc}^{22}$. Regarding the autoantibody profile, the pulmonary condition most associated with SSc is ILD and is related to anti-Scl-70 antibodies. Positive
ANA antibodies, but not anti-Scl-70 antibodies, have been observed in more than one-third of JSSc. Although no correlation with clinical features has been shown, the absence of anti-Scl-70 antibodies has been reported despite having ILD ${ }^{17}$. In our study, we observed a low percentage of these antibodies in children with ILD.

Regarding the frequency of pulmonary impairment, our results showed a higher prevalence than those reported in asymptomatic patients without pulmonary alterations according to HRCT and chest radiography ${ }^{18,22}$. Martini et al. ${ }^{23}$ reported a much lower prevalence of pulmonary fibrosis at diagnosis in patients with JSSc (20\%). At the initial evaluation, Panigada et al. ${ }^{21}$ found pulmonary disease in $58 \%$ of patients and increasing pulmonary disease after an 8-year follow-up. In our study, the median follow-up was 12 months, and we observed progression of the pulmonary disease in four patients.

FVC and DLCO tests are important parameters of lung function in the evaluation of JSSc. Low FVC and DLCO have been observed in SSc and ILD, for which they may be indicators of PAH. As only a few patients presented restrictive pulmonary pattern-manifested as FVC $<80 \%$ independently of ILD—and DLCO was not performed, we could not demonstrate this association. One study found that patients with SSc and significant ILD evaluated by HRCT had an average FVC value, with a high false-negative rate reported. In addition, patients with average FVC values show diffuse SSc more frequently despite evidence of fibrosis on $\mathrm{HRCT}^{24}$. Our patients presented mild symptoms-a few of them with spirometry alterations-but with changes in HRCT. Therefore, both pulmonary function tests and HRCT are recommended to increase the possibility of early detection of pulmonary disease.

Patients with mild ILD may be asymptomatic in the early stages of the disease. Subclinical lung disease should be specifically investigated and adequately monitored, mainly during the first years after diagnosis and in the case of cardiopulmonary symptoms. Interestingly, clinical or radiological evidence of severe or progressive pulmonary fibrosis on chest $\mathrm{X}$-rays is a strong predictor of death at presentation and is associated with increased mortality ${ }^{23,25}$. Six-minute walk test is a noninvasive indicator of cardiopulmonary function that proved to be the most useful in $\mathrm{PAH}$, with a poor correlation between distance traveled and measures of lung function ${ }^{26,27}$. The interpretation of 6MWT can be confusing in patients with SSc, as they have a cardiopulmonary or musculoskeletal disease and present combinations of cardiac involvement, even in the 


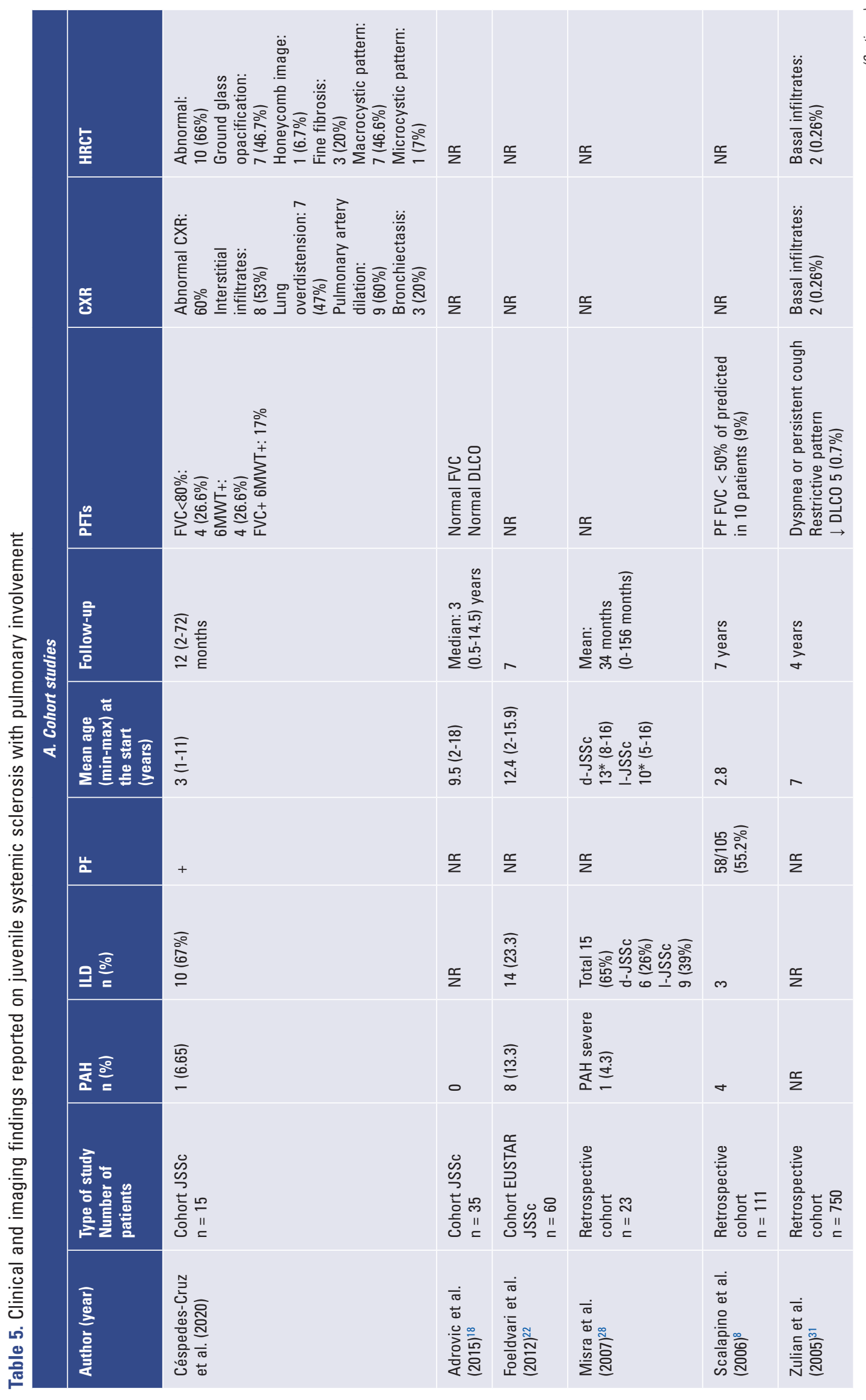




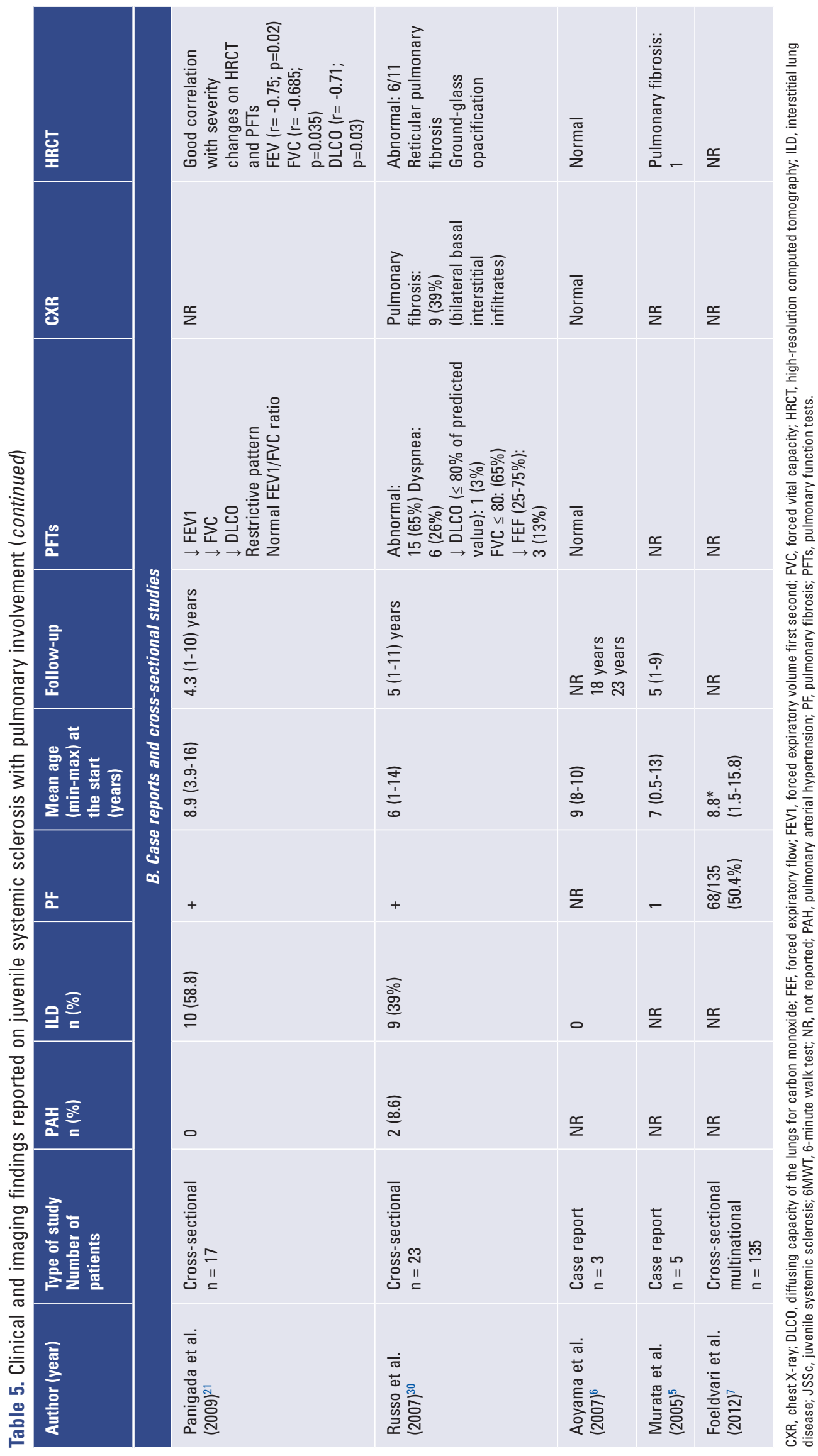


presence of normal echocardiogram, pulmonary disease, skin fibrosis, muscle damage, and joint disease ${ }^{27}$. An abnormal 6MWT was identified in a few patients of the present study. We recommend the follow-up of patients with cardiac and respiratory symptoms every 3 to 6 months and annually in the absence of clinical changes. Although optimal radiographic imaging could represent a challenge in infants, it is essential for an accurate diagnosis.

We observed a higher prevalence of I-JSSc, which indicates a mild condition as reported in the literature ${ }^{16}$. Although I-JSSc is more common in children, some studies found d-JSSc to be more prevalent ${ }^{28}$. Similar to our study, Morel et al. ${ }^{29}$ described the clinical characteristics of children with JSSC in our country and found pulmonary involvement in $100 \%$ of patients, with a predominance of the I-JSSc subtype. However, since it was not the study's primary objective, they did not describe the detailed characteristics of the pulmonary involvement.

Similar findings have been described regarding the progression of the disease, initial symptoms, diagnosis, and evolution: cardiopulmonary disease is the most frequent visceral involvement, leading to increased morbidity and death ${ }^{7,30}$. For PAH detection, transthoracic echocardiography has been proposed as a useful diagnostic tool among noninvasive tests, mainly because of its high specificity. However, due to the low sensitivity of noninvasive tests, right heart catheterization remains the gold standard for the confirmatory diagnosis of $\mathrm{PAH}$, although it cannot always be performed $^{16}$.

In adults, the PAH risk is $\geq 50 \%$ for every 10 years at the onset of scleroderma. The follow-up in our patients is still short, so it is advisable to continue it through adulthood. In this context, the most common cause of death in JSSc is heart failure followed by pulmonary involvement ${ }^{31}$. The main results in cohorts, case reports, and cross-sectional studies in patients with JSSc and pulmonary involvement are summarized in Table 5.

Our study has limitations such as the cross-sectional design, the absence of specific details on antibodies, and the lack of other cardiopulmonary parameters, including pro-BNP and DLCO testing. Although the sample size is small, a strength of our study is that it is an adequate number of patients in a single hospital center, considering that JSSC is an uncommon disorder during childhood.

As conclusions, we found that a high proportion of patients with JSSc with limited subtype presentation showed ILD, which occurs in patients with mild clinical findings. Therefore, early detection of JSSc and routine pulmonary monitoring once diagnosed are mandatory to avoid further complications.

\section{Ethical disclosures}

Protection of human and animal subjects. The authors declare that no experiments were performed on humans or animals for this study.

Confidentiality of data. The authors declare that they have followed the protocols of their work center on patient data publication.

Right to privacy and informed consent. The authors have obtained the written informed consent of the patients or subjects mentioned in the article. The corresponding author is in possession of this document.

\section{Conflicts of interest}

The authors declare no conflict of interests.

\section{Funding}

None.

\section{References}

1. Stevens AM, Torok KS, Li SC, Taber SF, Lu TT, Zulian F. Immunopathogenesis of juvenile systemic sclerosis. Front Immunol. 2019;10:1352.

2. Zulian F, Cuffaro G, Sperotto F. Scleroderma in children: an update. Curr Opin Rheumatol. 2013;25:643-50.

3. Richardson $\mathrm{AE}$, Warrier $\mathrm{K}$, Vyas $\mathrm{H}$. Respiratory complications of the rheumatological diseases in childhood. Arch Dis Child. 2016;101:752-8.

4. Yadav A, Yadav TP, Gupta V. Juvenile systemic sclerosis. J Indian Acad Clin Med. 2011;12:128-33.

5. Murata M, Sato S, Komura K, Shirasaki F, Hasegawa M, Takehara K. Clinical characteristics of juvenile systemic sclerosis in Japanese. J Rheumatol. 2005;32:1850-2.

6. Aoyama K, Nagai Y, Endo Y, Ishikawa O. Juvenile systemic sclerosis: report of three cases and review of Japanese published work. J Dermatol. 2007;34:658-61.

7. Foeldvari I, Tyndall A, Zulian F, Müller-Ladner U, Czirjak L, Denton C, et al. Juvenile and young adult-onset systemic sclerosis share the same organ involvement in adulthood: data from the EUSTAR database. Rheumatology (Oxford). 2012;51:1832-7.

8. Scalapino K, Arkachaisri T, Lucas M, Fertig N, Helfrich DJ, Londino AV Jr, et al. Childhood-onset systemic sclerosis: classification, clinical and serologic features, and survival in comparison with adult-onset disease. J Rheumatol. 2006;33:1004-13.

9. Zulian F, Woo P, Athreya BH, Laxer RM, Medsger TA Jr, Lehman TJA, et al. The Pediatric Rheumatology European Society/American College of Rheumatology/European League Against Rheumatism provisional classification criteria for juvenile systemic sclerosis. Arthritis Rheum. 2007;57:203-12.

10. Goemans N, Klingels K, van den Hauwe M, Boons S, Verstraete L, Peeters $C$, et al. Six-minute walk test: reference values and prediction equation in healthy boys aged 5 to 12 years. PLoS One. 2013;8:e84120.

11. Pacheco-Ríos N, Espitia-Hernández G, Sánchez-Ortiz AO. Caminata de 6 minutos en una población pediátrica de 6 a 12 años de edad derechohabiente del Hospital 1ํo de Octubre. Neumol Cir Torax. 2013;72:147-53.

12. Ionescu R, Rednic S, Damjanov N, Varjú C, Nagy Z, Minier T, et al. Repeated teaching courses of the modified Rodnan skin score in systemic sclerosis. Clin Exp Rheumatol. 2010;28:S37-41.

13. Fan LL, Deterding RR, Langston C. Pediatric interstitial lung disease revisited. Pediatric Pulmonol. 2004;38:369-78. 
14. Pérez-Padilla R, Regalado-Pineda J, Rojas $M$, Catalán $M$, Mendoza L, Rojas R, et al. Spirometric function in children of Mexico City compared to Mexican-American children. Pediatr Pulmonol. 2003;35:177-83.

15. Ivy DD, Abman SH, Barst RJ, Berger RMF, Bonnet D, Fleming TR, et al. Pediatric pulmonary hypertension. J Am Coll Cardiol. 2013;62:D11726

16. Hsu VM, Moreyra AE, Wilson AC, Shinnar M, Shindler DM, Wilson JE, et al. Assessment of pulmonary arterial hypertension in patients with systemic sclerosis: comparison of noninvasive tests with results of right-heart catheterization. J Rheumatol. 2008;35:458-65.

17. Martini G, Foeldvari I, Russo R Cuttica R, Eberhard A, Ravelli A et al. Systemic sclerosis in childhood: clinical and immunologic features of 153 patients in an international database. Arthritis Rheum 2006:54:3971-8

18. Adrovic A, Oztunc F, Barut K, Koka A, Gojak R, Sahin S, et al. The frequency of pulmonary hypertension in patients with juvenile scleroderma. Bosn J Basic Med Sci. 2015;15:30-5

19. Matuszewska G, Zaniewicz-Kaniewska K, Włodkowska-Korytkowska M Smorawinska P, Saied F, Kunisz W, et al. Radiological imaging in pediatric rheumatic diseases. Pol J Radiol. 2014;79:51-8.

20. Zulian F, Balzarin M, Birolo C. Recent advances in the management of juvenile systemic sclerosis. Expert Rev Clin Immunol. 2017;13:361-9.

21. Panigada S, Ravelli A, Silvestri M, Granata C, Magni-Manzoni S, Cerveri I et al. HRCT and pulmonary function tests in monitoring of lung involvement in juvenile systemic sclerosis. Pediatr Pulmonol. 2009;44:1226-34

22. Foeldvari I, Zhavania M, Birdi N, Cuttica RJ, de Oliveira SHF, Dent PB, et al. Favourable outcome in 135 children with juvenile systemic sclerosis: results of a multinational survey. Rheumatology (Oxford). 2000;39:556-9.
23. Martini G, Vittadello F, Kasapçopur O, Manzoni SM, Corona F, Duarte-Salazar $C$, et al. Factors affecting survival in juvenile systemic sclerosis. Rheumatology (Oxford). 2009;48:119-22.

24. Suliman YA, Dobrota R, Huscher D, Nguyen-Kim TD, Maurer B, Jordan S, et al. Brief report: pulmonary function tests: high rate of false-negative results in the early detection and screening of scleroderma-related interstitial lung disease. Arthritis Rheumatol. 2015;67:3256-61.

25. Schoenfeld SR, Castelino FV. Interstitial lung disease in scleroderma. Rheum Dis Clin North Am. 2015;41:237-48.

26. Douwes JM, Hegeman AK, van der Krieke MB, Roofthooft MT, Hillege HL, Berger RM. Six-minute walking distance and decrease in oxygen saturation during the six-minute walk test in pediatric pulmonary arterial hypertension. Int J Cardiol. 2016;202:34-9.

27. Andrade FM, Oliveira AD, Lopes AJ. Ventilation distribution as a contributor to the functional exercise capacity in patients with systemic sclerosis-associated interstitial lung disease without pulmonary hypertension. Braz J Med Biol Res. 2019;52:e8513.

28. Misra $R$, Singh $G$, Aggarwal $P$, Aggarwal $A$. Juvenile onset systemic sclerosis: a single-center experience of 23 cases from Asia. Clin Rheumatol. 2007;26:1259-62.

29. Morel Z, Benadón E, Faugier E, Maldonado MR. Características clínicas de niños con esclerodermia en un hospital de referencia. Reumatol Clin. 2009;5:158-62.

30. Russo RA, Katsicas MM. Clinical characteristics of children with juvenile systemic sclerosis: follow-up of 23 patients in a single tertiary center. Pediatr Rheumatol Online J. 2007;5:6.

31. Zulian F, Vallongo C, Woo P, Russo R, Ruperto N, Harper J, et al. Localized scleroderma in childhood is not just a skin disease. Arthritis Rheum. 2005;52:2873-81. 